\title{
Clinical Evaluation of Some Biochemical Parameters from Patients in Heamodialysis Room
}

\author{
Fatin F. Al-Kazzaz*
}

Date of acceptance $1 / 3 / 2010$

\begin{abstract}
As a marker of systemic inflammation, raised (C-reactive protein (CRP)) concentrations which are still within the normal range have been associated with an increased inflammation of chronic renal diseases (CRD).

The current study aimed to establish potential determinats of raised CRP concentrations in patients who treated in Heamodialysis room,then study the relationship between CRP\& some biochemical parameters related CRD

We used a CRP latex reagents Kit which is based on an immunological reaction between CRP antisera bounded to the biologically inert latex particles or with CRP in the test specimens of 19 patients with (CRD) mean age 48 years, range $=$ $30 \rightarrow 65 \&$ in 21 healthy subjects as control group their age range $=30 \rightarrow 45$ years.
\end{abstract}

The results are classified according to visible agglutination to:

1-A positive result / is indicated by the obvious agglutination pattern of the latex, in a clear solution.

2-A negative result / is indicated by no change in the latex suspension on the test slide.

Then, we correlated the results of the precipitin test with the quantitative data on C-reactive protein.

This study has found that

CRP concentrations in patients with CRD were increased very clearly than normal subjects, and established that CRP concentration in male was more than in female for patients specimens. Biochemical studies have shown raising (CRP) concentration is a marker of systemic inflammation.

The relation between CRP \& S.creatinine, hemoglobine ,blood sugar is negative, while positive with blood urea .

Other biochemical parameter related to CRD" blood urea, blood creatinine \& hemoglobine and blood sugar" were assayed for both subjects in order to asses the disease by compared the results.

\section{Abbreviation:}

CRP:C-reactive protein, CRD: Chronic renal diseases, F: Female, M: Male, $\mathrm{Hb}$ : hemoglobin, BU: blood Urea, S.Cr: Serum creatinine, BS: blood sugar, nCRP: native CRP, MCRP: Matified CRP.

Key words: C-reactive protein (CRP), Heamodialysis room, chronic renal diseases.

\section{INTRODUCTION}

Renal insufficiency may

develop, when nephrons are destroyed-

infection of renal pelvis and nephrons, as in chronic glomerulonephritis, or loss of a kidney - or when kidney College of science, AL-Mustansiryah University function is reduced by damage caused 
by diabetes mellitus, arterio-sclerosis or blockage by kidney stones. This can cause hypertension, which is due primarily to the retention of salt, water and uremia.The inability to excrete urea is accompanied by an elevated $\mathrm{H}^{+}$ concentration (acidosis) and $\mathrm{K}^{+}$ concentration, which are more immediately dangerous than the levels of urea ${ }^{(1)}$. So, if the blood contains too much creatinine or urea nitrogen and urine contains protein,kidneys may not be functioning properly ${ }^{(2)}$.

Renal failure is one of the main reason $\mathrm{s}$ (for the cause) for death in Iraq in the years $2004 \& 2005$ for patients with $\geq 5$ years old(29).

Creatinine is a waste product in the blood created by the normal breakdown of muscle during activity. Healthy kidneys take creatinine out of the blood and put it in the urine to leave the body. When kidneys are not working well, creatinine builds up in the blood. In many assays the normal creatinine range is 0.6 to $1.2 \mathrm{mg} / \mathrm{dl}^{(2)}$. Also, blood carries protein for use by cells throughout the body. After the cells use the protein, the remaining waste product is retuned to the blood as urea, a compound containing nitrogen. Healthy kidneys take urea out of the blood and send it to bladder in the urine, if kidneys are not working well, the urea will stay in the blood. Normal blood contains 7 to 20 $\mathrm{mg} / \mathrm{dl}^{(2)}$. Patients with uremia or the potential for developing uremia often placed on a dialysis machine. Dialysis refers to separation of molecules on the bases of their ability to diffuse through on artifical selectively permeable membrane $^{(1)}$.

This principle is used in the 'artifical kidney machine" for hemodialysis.Urea \& other wastes in the patient's blood can easily pass through the membrane pores wherease plasma proteins are left behind (1). Hemodialysis is usually performed at a dialysis center three times per week for 3 or 4 hours $^{(2)}$

Inflammation is triggered within days of tissue injury or infection, stimulating a number of systemic \& metabolic changes. One of the most dramatic changes is increase in blood serum levels of an inflammatory marker known as Creactive protein (CRP) ${ }^{(3)}$ C-reactive protein (CRP) is an acute plasma protein, produced by the liver \& was originally discovered by Tillett \& Francis in 1930 as a substance in the serum of patients with inflammation that reacted with the C-polypeptide of pneumococcus ${ }^{(3)}$.

C-Reactive protein (CRP) belongs to the pentraxin family of proteins, $\quad$ So-called because it has five identical subunits, encoded by a single gene on chromosome 1 , which associate to form a stable disc-like pentameric structure ${ }^{(4)}$.

CRP occurs in at least two different conformationally distinct forms, native CRP(nCRP)and modified $(\mathrm{mCRP})^{(5)}$.nCRP is a cyclic disc composed of five identical,nonglycosylated subunits. It is highly soluble serum protein that shows calcium - dependent affinity for phosphate monoesters. As with nCRP, mCRP is also a naturally occurring stable protein, found in the fibrous tissues of normal blood vessel intima (6). The formation of mCRP from CRP is non-proteolytic and irreversible ${ }^{(7)}$. There is an increasing evidence that each isomeric form of CRP induces different immunologic and inflammatory responses ${ }^{\left({ }^{8}\right)}$.

Laboratory testing for C reactive protein is used to Identify the presence, severity of inflammation \& to monitor the patients response to medical treatment ${ }^{(9)}$.

CRP is a sensitive but nonspecific indicator of acute injury, infection, inflammation, 
musculoskeletal disorders, malignant lymphomas, rheumatic fever, necrosis $\&$ arthritis. Very high CRP levels are found in acute myocardial infarction, sepsis \& following surgery ${ }^{(9)}$ CRP concentration increases in the blood within a few hours after the onset of an infection or other inflammatory injury. An elevation in CRP level often precedes pain, fever or other clinical indicators ${ }^{(9)}$

The level of CRP can jump a thousand- fold in response to inflammation and then drop relatively quickly as soon as the inflammation resolves ${ }^{(9)}$.

CRP tests are not indicated for the diagnosis of specific disease processes but rather as a general marker of infection and inflammation that alerts medical professionals to the fact that further testing and/or treatment may be necessary. CRP testing is utilized in patients with inflammatory diseases (e.g., inflammatory bowel disease, etc.) and auto immune diseases. Systemic lupus, erythematosus, rheumatoid arthritis, diabetes mellitus, multiple sclerosis, etc.) In order to assess the disease activity and to monitor treatment effectiveness ${ }^{(9)}$.

A high or increasing amount of CRP in the blood suggests an acute infection or inflammation. Although a result above $1 \mathrm{mg} / \mathrm{dl}$ is usually considered high for CRP, most infections and inflammations result in CRP levels above $10 \mathrm{mg} / \mathrm{dl}$. Adclining CRP level indicates a reduction in inflammation. ${ }^{(9)}$

CRP results below $1 \mathrm{mg} / \mathrm{dl}$ suggest that active inflammation has resolved. Reference ranges vary, depending on the laboratory methodology and the reference population (e.g., age, sex, ete. $)^{(9)}$.

In haemodialysis, mean CRP levels are eight- folds higher than in healthy control being a powerful predictor of all cause and cardiovascular death even after a follow -up period of 4 years (24)

The aim of current study is establish potential determinats of raised CRP concentrations in patients who treated in Heamodialysis room, then study the relationship between CRP\& some biochemical parameters that related CRD

\section{SUBJECTS \& METHODS:}

Patients with chronic renal disease CRD $\mathrm{n}=19, \mathrm{~F}=7, \mathrm{M}=12$, age range $30 \rightarrow 65$ years, who were with normal blood pressure, no smoking, no diabetic disease or any inflammation except chronic renal disease, collecting from hemodialysis room in Medicine City Hospital, healthy control subjects $\mathrm{n}=21, \mathrm{~F}=7, \mathrm{M}=14$, age rang $=30$ 45 are participated in this study.

\section{C-Reactive Protein Assay:}

The CRP reagent kit used here is based on an immunological reaction between CRP antisera bound to biologically inert latex particles \& CRP in the test specimen. When serum containing greater than $0.8 \mathrm{mg} / \mathrm{dl}$ CRP is mixed with the latex reagent, visible agglutination occurs ${ }^{(10,11)}$. Then, we correlated our results of the precipitin test with the quantitative data on CRP.

Table(1):Correlation of the results precipitin test with the quantitative data on $C R P^{(13)}$ :

\begin{tabular}{|c|c|}
\hline $\begin{array}{c}\text { Piecipitin } \\
\text { reaction }\end{array}$ & $\begin{array}{c}\text { Mean concentration } \\
\text { CRP(mg/dl) }\end{array}$ \\
\hline++++++ & 3.3 \\
\hline+++++ & 2.7 \\
\hline++++ & 2.3 \\
\hline+++ & 1.2 \\
\hline++ \pm & 1.01 \\
\hline++ & 0.5 \\
\hline+ \pm & 0.4 \\
\hline+ & 0.2 \\
\hline \pm & 0.1 \\
\hline Trace & 0.06 \\
\hline
\end{tabular}

The latex kit is provided by

Atlas Medical/Cambrige. Other 
parameters were measured as the following assays:

2.Blood urea Assay:

Serum urea value was assayed according to the enzymatic method (submitted by HUMAN-Germany) which accur in an alkafine medium, the ammonium ions react with the salicylate and hyperchloride ot form a green colored indophenol) which absorb at $580 \mathrm{~nm}$.

\section{Blood Creatinine Assay:}

This method is based on the reaction of creatinine with alkaline picrate to give a red colour creatinine picrate which can be estimated by spectrophotometer. There are complex of creatinine picrate absorbs at $520 \mathrm{~nm}$ creatinine was estimated according to the color metric method by using creatinine kit which is provided by HUMAN-Germany Creatinine kit is provided by RANDOX/U.K.D

\section{Haemoglobin Assay( by Randox U.K)}

In the presence of alkaline potassium ferricyanide, $\mathrm{Hb}$ is oxidised to methaemoglobin. This then reacts with potassium cyanide to form cyanomethaemoglobin which absorbs at $540 \mathrm{~nm}$. The intensity of this absorbance is directly related to total haemoglobin concentration.

Heamoglobin in this study was assayed by using $\mathrm{Hb}$ kit which is provided by RANDOX/U.K.D

\section{Blood Glucose Assay:}

In the trinder reaction, the glucose is oxidized to D-gluconate by glucose oxidase with the formation of hydrogen peroxide. In the presence of peroxidase, a mixture of phenol and 4aminoantipyrine is oxidized by hydrogen peroixide, to form a red quinoneimine dye proportional to the concentration of glucose sample. Kit was provided by LINEAR chemicals spain.

\section{RESULTS:}

Table

(2) lists the characteristics of the chronic renal disease CRD who participated in this study with the results of their $\mathrm{Hb}, \mathrm{CRP}$, B.U, S Great, and BS.

Table (2): Results of serum C-RP, Bu, Hb \& Crin patients with chronic renal diseases with their corresponding controls.

\begin{tabular}{|c|c|c|c|c|c|c|c|c|}
\hline \multirow{3}{*}{$\begin{array}{l}\text { Subject } \\
\text { Parameters }\end{array}$} & \multicolumn{4}{|c|}{ Control } & \multicolumn{4}{|c|}{ Patients } \\
\hline & Male $\mathrm{N}=14$ & & Female $\mathrm{N}=7$ & & Male $\mathrm{N}=12$ & & Female $\mathrm{N}=7$ & \\
\hline & Mean \pm SD & SE & Mean \pm SD & SE & Mean \pm SD & $\mathrm{SE}$ & Mean \pm SD & $\mathrm{SE}$ \\
\hline C-RP mg dl & $0.06 \pm 0.0000$ & 0.000 & $0.06 \pm 0.000$ & 0.000 & $0.321 \pm 0.429$ & 0.124 & $0.305 \pm 0.426$ & 0.1 \\
\hline $\mathrm{B}-\mathrm{U} \mathrm{mg} / \mathrm{dl}$ & $37.625 \pm 6.859$ & 1.980 & $34.28 \pm 3.90$ & 1.475 & $136.58 \pm 43.34$ & 12.513 & $120.14 \pm 36.71$ & 13.876 \\
\hline BS mg dl & $110.416 \pm 11.188$ & 3.229 & $101.714 \pm 10.11$ & 3.821 & $118.16 \pm 52.21$ & 15.074 & $84.42 \pm 14.88$ & 5.626 \\
\hline $\mathrm{Hb} \mathrm{mg/dl}$ & $13.89 \pm 1.35$ & 0.393 & $11.48 \pm 0.926$ & 0.350 & $10.29 \pm 2.316$ & 0.668 & $9.54 \pm 2.59$ & 0.951 \\
\hline S.Cr mg dl & $0.87 \pm 0.213$ & 0.062 & $0.78 \pm 0.203$ & 0.077 & $6.46 \pm 2.62$ & 0.757 & $6.72 \pm 1.89$ & 0.717 \\
\hline
\end{tabular}

The results of studied parameters are expressed as Mean $\pm \mathrm{SD}$ and standard error SE for male \& female

These result are compared by using the analysis of variance (AOVA). The differences with $\mathrm{P}$ value of less than 0.05 are considered statistically significant (table3 ).
Table (3): Results of analysis of variance (ANOVA) for the two sex of patients with chronic renal disease and the control groups.

\begin{tabular}{|c|c|c|c|c|}
\hline $\begin{array}{c}\text { Subjects } \\
\text { Parameters }\end{array}$ & \multicolumn{2}{|c|}{$\begin{array}{c}\text { Control \& } \\
\text { patients } \\
\text { (Male) }\end{array}$} & \multicolumn{2}{c|}{$\begin{array}{c}\text { Control \& } \\
\text { patients } \\
\text { female }\end{array}$} \\
\hline C-RP & 0.059 & N.S & 0.178 & N.S \\
\hline BU & 0.000 & S & 0.001 & S \\
\hline BS & 0.629 & N.S & 0.095 & N.S \\
\hline Hb & 0.001 & S & 0.118 & N.S \\
\hline S.Cr & 0.000 & S & 0.000 & S \\
\hline
\end{tabular}

NS: Non significant $\mathrm{S}=$ Significant 


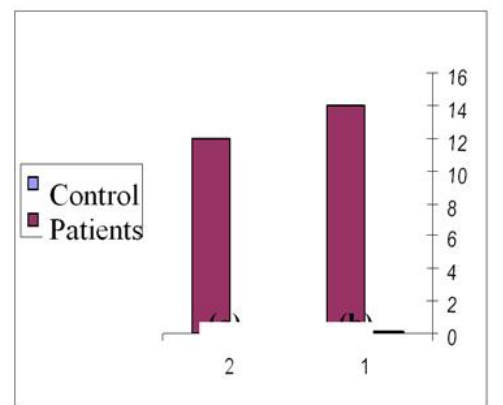

Figure(1): compression CRP concentration in serum between controls \&patients with CRD in (1male, 2-female)

As shown in figure 1 which compressed the CRP concentration in these patients,
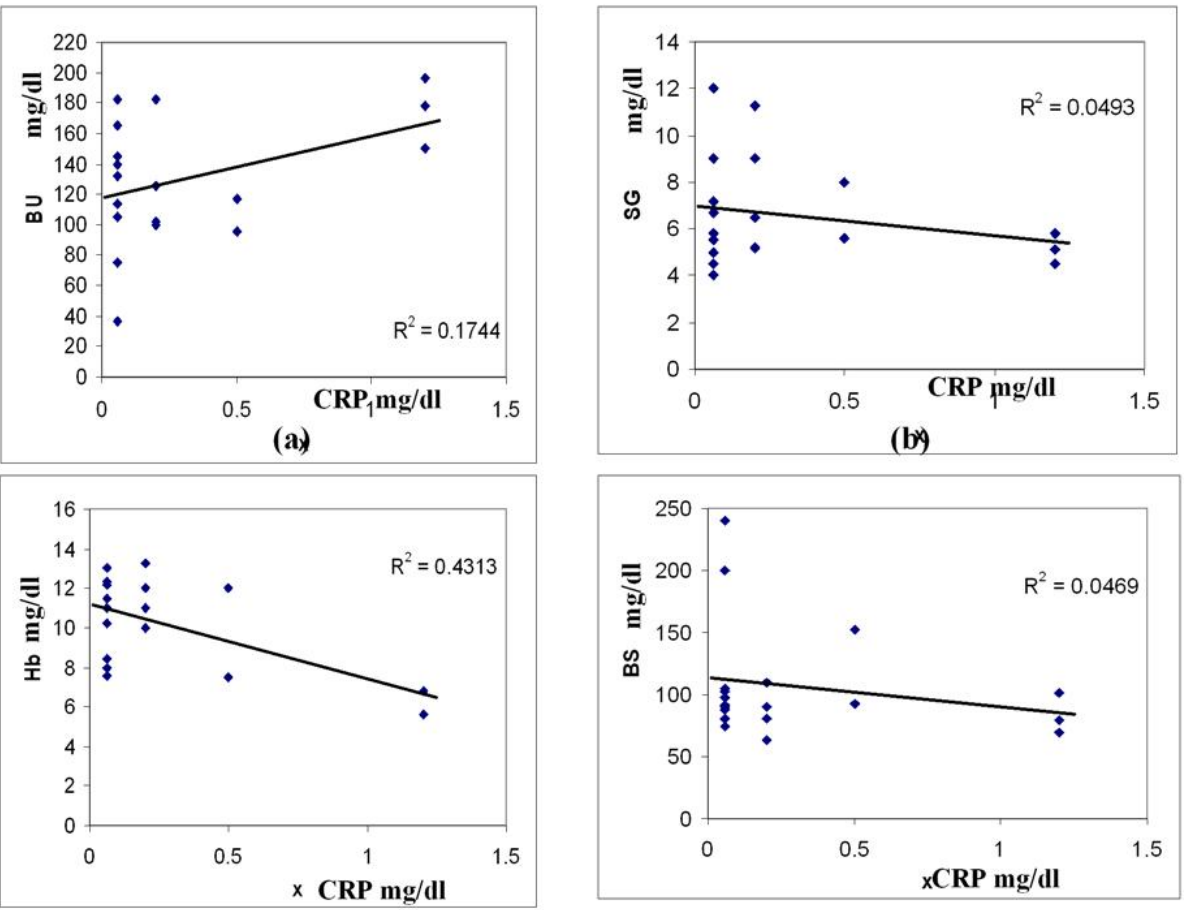

(c) generally CRP levels in patients were more than in control subjects (patients mean $=0.386 \mathrm{mg} / \mathrm{dl}$ control mean $=0.06 \mathrm{mg} / \mathrm{dl}$ ).

Also it's clearly the male had more CRP concentration than in female in the patients samples, as in table (3)

We provided that there is a positive correlation factor $\left(\mathrm{R}_{2}=0.1744\right)$ between CRP \& blood urea while negative correlation factor between CRP and serum creatinine, heamoglobin, blood sugar $\left(\mathrm{R}_{2}=\right.$ $0.0493,-0.4313,-0.0469)$ respectively in patients who suffer from chronic renal disease as shown in figure (2)a, b, c, d. (d)

Figure (2): The Correlation between:

$A-C R P \& B U, \quad B-C R P \& S G$

$C-C R P \& H b, D-C R P \& B S$ 


\section{DISCUSSION:}

CRP has been very stably conserved in the evolution ${ }^{(14,15,16)}$, and no structural polymorphism or deficiency of CRP has yet been reported in humans, suggesting that this protein has important normal functions that contribute to survival. In experimental models, CRP is protective against pneumococcal infection ${ }^{(17,18)}$ and may contribute to innate immunity to other microorganisms to which it binds (19, 20)

CRP also probably plays an important role in scavenging autologous ligands and preventing development of autoimmunity. This does not mean however, that CRP may not also contribute to pathogenesis of disease, especially conditions developing in post reproductive later life. Natural selection is 'blind' to phenomena occurring after reproduction, provided they do not affect viability of the species as awhole (21)

And as regarded by Kushner ${ }^{(22)}$ C-RP concentrations less than 0.05 $\mathrm{mg} / \mathrm{dl}$ are considered normal; between 0.06 and $10 \mathrm{mg} / \mathrm{dl}$ as moderate increases and more than $10 \mathrm{mg} / \mathrm{dl}$ as a marker increases and more than $10 \mathrm{mg} / \mathrm{dl}$ as a marked increases. The majority of patients with very high levels have bacterial infection, whereas more moderate degrees of elevation are seen in most chronic inflammatory states $^{(22)}$.In general, CRP values rarely exceed 6 or $8 \mathrm{mg} / \mathrm{dl}$ in patients with chronic inflammatory states or malignancies. Concentrations greater than this should raise the possibility of superimposed bacterial infection ${ }^{(23)}$.

The present study as shown in (Table $2 \& 3$ ) that patients with chronic renal disease have highly non significant elevations $(\mathrm{P}>0.05)$ in $\mathrm{CRP}$ \& BS levels for both male \& female, compared to the age matched healthy controls. The same changes in renal biochemical test (i.e., in $\mathrm{BU} \& \mathrm{SCr}$ ) were observed in the same patients with differences in $\mathrm{P}$ value, it is highly significant $\quad(\mathrm{P}<0.05) . \quad$ Serum hemoglobin concentration revealed significant decrease $(\mathrm{P}<0.05)$ in male, while in female it is changed non significant $(\mathrm{P}>0.05)$.

The results of this study are in agreement with Susanne et.al, ${ }^{(24)}$ Who found that tubular modified CRP staining increased with declining renal function \& increasing serverity of histological lesions in patients with advanced diabetic nephropathy, whether it may serve as a marker of progression deserves further immunohistochemical analysis in patients with early nephropathy ${ }^{(24)}$. female/male difference $(0.305 / 0.0 .321)=0.95$ may simply be associated with an increased prevalence of subclinical urinary infection in woman. This is disagreament with our value 0.950 \& with another study by Al-kubayssy who found that the C-RP raised in cardiovascular patients for both sex but in male more than in female $(25,26,28)$.

The amount of CRP produced by the body varies from person to other affected by an individual's genetic make up (accounting for almost has variation in CRP levels between different people) and life style. High level tend to be found in individuals who smoke, have high blood pressure, overweight and don't exercise ${ }^{(3,23)}$

The correlation test done by using excel 2003, according to the program $\pm(0.1-0.35)$ consider as weak consider $\quad \pm(0.35-0.5) \quad$ consider correlation and $\pm(0.5-1.0)$ consider as strong correlation.

The possible correlation between $\mathrm{C}$-reactive protein (CRP) 
levels, and other relate biochemical parameters in each sex of patients who suffer from chronic renal disease (i.e., $\mathrm{BU}, \mathrm{BS}, \mathrm{Hb} \& \mathrm{~S} . \mathrm{Cr}$.) was investigated by the value of correlation coefficient and significant value (table 4).

Results of CRP shown that high positive correlation regarded between $\mathrm{CRP}$ with $\mathrm{Bu}(\mathrm{r}=0.518)$ for male, while a weak positive correlation $(r=0.218)$ for female with in significant relation $(\mathrm{P}>0.05)$.

A weak negative correlation between CRP with BS ( $\mathrm{r}=-0.242)$ for male $(r=-0.408)$ for female with in significant relation.

The correlation between CRP $\& \mathrm{Hb}$ shown strong negative for both $\operatorname{sex}(r=-0.602$ for male \& $r=-.0782$ for female) with highly significant relation $(\mathrm{P}<0.05)$, while highly weak negative correlation between C-RP and $\mathrm{SCr}$ for both sex $(r=-0.297$ for male \& $r=-0.037$ for female) with in significant relation $(\mathrm{P}>0.05)$.

Table (4): Correlation coefficient of

C-Reactive Protein (C-RP) with

other biochemical parameters in sera of male $\&$ female with chronic renal disease.

\begin{tabular}{|c|c|c|c|c|}
\hline \multicolumn{1}{|c|}{ renal disease. } \\
$\begin{array}{c}\text { CRP } \\
\text { Tests }\end{array}$ & $\begin{array}{c}\text { C-RP } \\
\text { male }\end{array}$ & $\begin{array}{c}\text { C-RP } \\
\text { female }\end{array}$ & \\
\hline & $\begin{array}{c}\mathrm{r} \\
\text { value }\end{array}$ & $\begin{array}{c}\text { Significant } \\
\text { value }\end{array}$ & $\mathrm{r}$ value & $\begin{array}{c}\text { Significant } \\
\text { value }\end{array}$ \\
\hline $\mathrm{BU}$ & 0.518 & 0.085 & 0.218 & 0.639 \\
\hline $\mathrm{BS}$ & -0.242 & 0.448 & -0.408 & 0.363 \\
\hline $\mathrm{Hb}$ & -.0602 & 0.038 & -0.782 & 0.038 \\
\hline $\mathrm{SCr}$ & -0.297 & 0.349 & -0.037 & 0.937 \\
\hline
\end{tabular}

The good positive correlation between CRP\&blood urea leads us to conclude that raising urea level in patients with end-stage renal disease causes raising CRP (acute phase reactant), in other word CRP is a good marker for screening those patients.

A weak negative correlation factor between CRP\&serum creatinine figure (2), also we found a negative correlation factor between CRP \& blood sugar, $\mathrm{Hb} \&$ suppose that sugar level doesn't have effect on patient's with end-stage of renal disease and these patients also suffer from anaemia $\mathrm{Hb} \leq 10 \mathrm{~g} /$ l. figure(2), table (3)

\section{REFERENCES:}

(1) Stuart I.Fox: Human physiology $\left(7^{\text {th }}\right.$ Ed)McGraw-Hill $/$ North America. (2002); Chap.17: p: 554.

(2) NIDDK Web MD public information: Your Kidneys and how they work. National Instituted of Health -2006.

(3) $\mathrm{AHA} / \mathrm{CDC}$ Scientific Statement: Markers of inflammation and cardiovascular disease application to clinical and public health practice: A statement for health care professionals from the centers for disease control and prevention and the American Heart Assoication-2003.

(4) Betteridge D.J., Gibson J.M., Sager P.T.: Comparison of effectiveness of rosuvastatin versus at or vastatin on the achievement of combined CRP $(<2 \mathrm{mg} / \mathrm{dl})$ and low-denisty lipoprotein cholesterol $(<70 \mathrm{mg} / \mathrm{dl})$ targets in patients with type 2 diabetes

mellitus.Am.J.Cardiol.2007;100(8): 1245-8.

(5) Potempa L.A, Siegel T.N., Fiedel B.A., etal.: Expression, detection \& assay of neoantigen (Neo-CRP) associated with a free, human Creactive protein subunit. Mol.Immunol.1987; 24:531-541.

(6) Diehl EE, Haines GK., Radosevich J.A., etal.: Immunohistochemical localization of modified C-reactive protein antigen in normal vascular tissue.AM.J.Med.Sci: 2000; 319:7983.

(7) Kresy 1 J.J., Potempa L.A., Anderson B.E.:Conversion of native oligomeric to amodified monomeric from of human C- 
reactive protein.Int.J.Biochem cell.Biol.1998;30:1415-1426

(8) Zouki C., Haas B., Chan J.S.D,et.al., :Loss of pentameric symmetry of $\mathrm{C}$-reactive protein is associated with promotion of neutrophil-endothelial cell adhesion.T.Immunol.2001;167:535 5-5361.

(9) Bhagats. Gaiha M., Sharma V.K.et.al:A comparative evaluation of C-reactive protein as a short-term prognostic marker in severe unstable angina-a preliminary study, J.Assoc. physicaians India, 2003 Apr;51:349-354.

(10) Harold C.,Anderson M.D.,Maclyn M.C.,etal,:Determination of Creactive protein in the blood as a measure of the activity of the disease process in acute rheumatic fever, Ameri.J.Med. $1950 ; 8: 445-455$

(11) Rutter M., Meigs J., Sulivan L., et al.: CR-P the metabolic syndrome and predication of cardiovascular events in the Framingham off spring study-Circulation-2004; 10:380-385.

(12) Freeman D.J., Norrie J., Caslake M.J., et al.: CRP is an independent predicator of risk for the development of diabetes Diabetes. 2002; 51: 1596-600.

(13) Harrison F.W., Maclyn M., The measurement of C-reactive protein in human sera. Comparison of the clinical tests on the basis of a quantitative method, Clini.Inves, 1951; 30:616-622.

(14) Pepys.M.B.,Balt3 M.L.,:Acute phase proteins with special reference to $\mathrm{C}$-reactive protein and related proteins (pentaxins) and serum amyloid A protein, Adv.Immunol., 1983;34:141-212.

(15) Pepys M.B., Dash A.C., Fletcher T.C.,et.al.:Analogues in other mammals and in fish of human plasma proteins C-reactive protein and a amyloid $\mathrm{P}$ component, Nature, 1978; 273:168-170.

(16) Baltz M.L., de Beer F.C., Feinstein A., et.al.:Phylogenetic aspects of C-reactive protein and related protein, Ann. NyAcad.Sci., 1982; 389:49-75.

(17) Mold C., Nokayama S., Holzer T.J., et.al.: C-reactive protein is protective against streptococcus peneumoniae infection in mice, J.Exp.Med., 1981;154:1703-1708.

(18) Schwedler S.B., Amann K., Wernicke $\mathrm{K}$., et al: native CRP increases whereas modified CRP reduces atheroscherosis in apolipoprotein E-Knockout mice Circulation. 2005; 112(7): 10161023.

(19) Weiser J.N., Pan N., Mc Gowan k.l., et. al.: Phosphorylcholine on the lipopolysaccharide of haemophilus influenzue contributes To persistence in the respiratory tract and sensitivity to serum killing mediated by $\mathrm{C}$. reactive protein , J. exp . med., 1998; 187: 631-640.

(20) M.Griselli, J. Herbert, W.L. Hutehinson, et al:: C-reactive protein and complement are important mediators of tissue damage in acute myo cardial infarction,$J$. Exp.Med.,1999;190:1733-1740.

(21) Pepys M.B.,:The lumleian lecture.C-reactive protein \& amyloidosis ;from protein to drug In Williams G.,ed.Horizons in Medicine, 1999;10:397-414.

(22) Pepys M.B., Hawkins P.N., Kahan M.C., et al.: Proinflammatory effects of bacterial recombinant human CRP are caused by contamination with bacterial products, not by CRP itself. Circ.Res. 2005; 97(11):e97-e103. 
(23) Pepys M.B.: CRP or not CRP? That is the question. Arterioscler. Thromob. Vasc. Biol.2005; 25(6):1091-1094.

(24) Susanne B.S.,Frank G.,Jobst D.,et.al.:Tubular staining of modified C-reactive protein in diabetic chronic kidney disease, Oxford.J., 2003; 18://:2300-2307.

(25) Krijnen P.A., Ciurana C., Cramer $\mathrm{T}$,, et al.: IgM colocalises with complement and CRP in infracted human myocardium.J.Clin.Pathol. 2005; 58(4): 382-388

(26) Yudkin J.S.,Blauth C.,Drury P.,et.al.:Prevenation and management of cardiovascular disease in patients with diabetes mellitus:an evidence base.Diabetis ～Med.,1996;13:S 101-121.

(27) E.S.Kilpatrick, B.C.Keevil, C.Jagger, et.al:Determinations of raised C-reactive protein concentration in type 1 diabetes.J.Med.2000;231-236.

(28) Al-Kuppaysy R.O.: Biochemical study on total homocysteine and high sensitive CRP in estaleshed cardiovascular patients, AlMustansiriyah Un., 2005.

(29). د.نغم الخفاجي و د. عبدالرحمن داود: الدليل

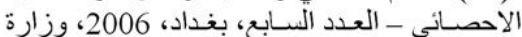
الصحةـ قنم الاحصاء الصحي والعي لغياتي.

\section{التقدير السريري لبعض المتغيرات الكيموحياتية لاى المرضى الراقدين في وحدة غسل الكلية}

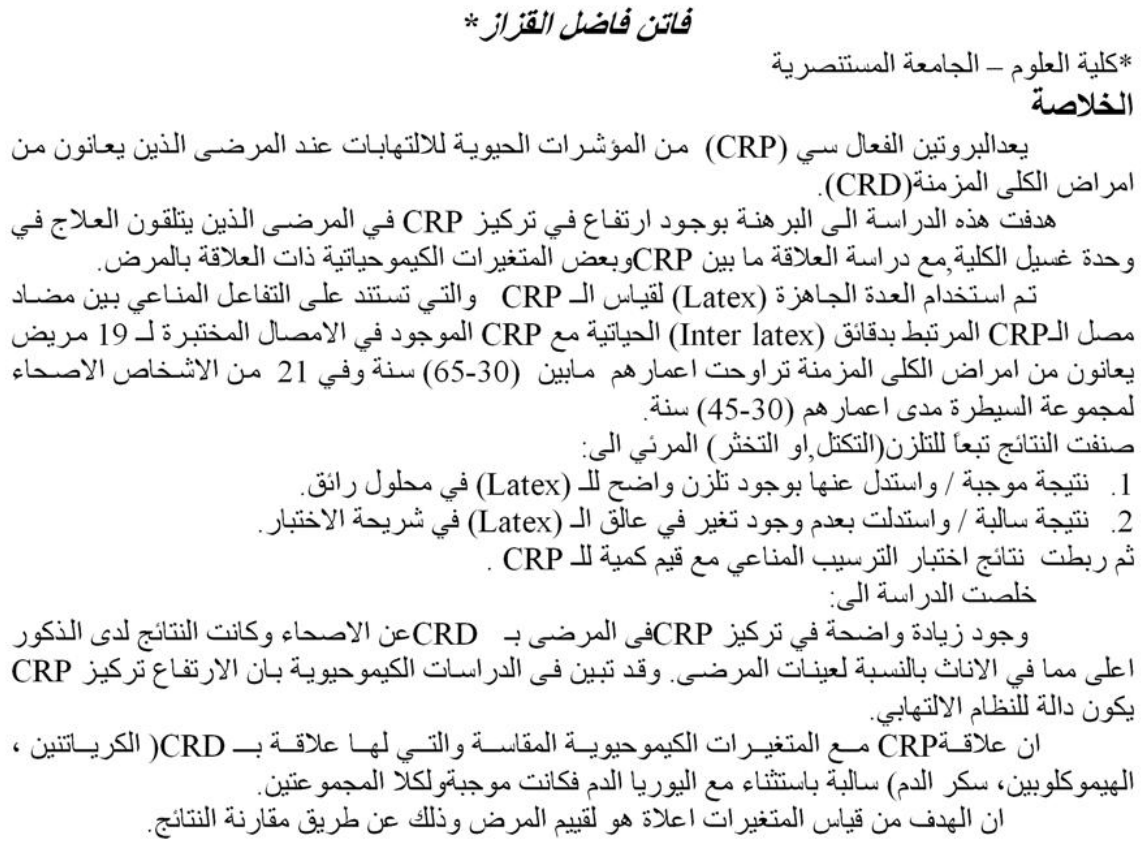

